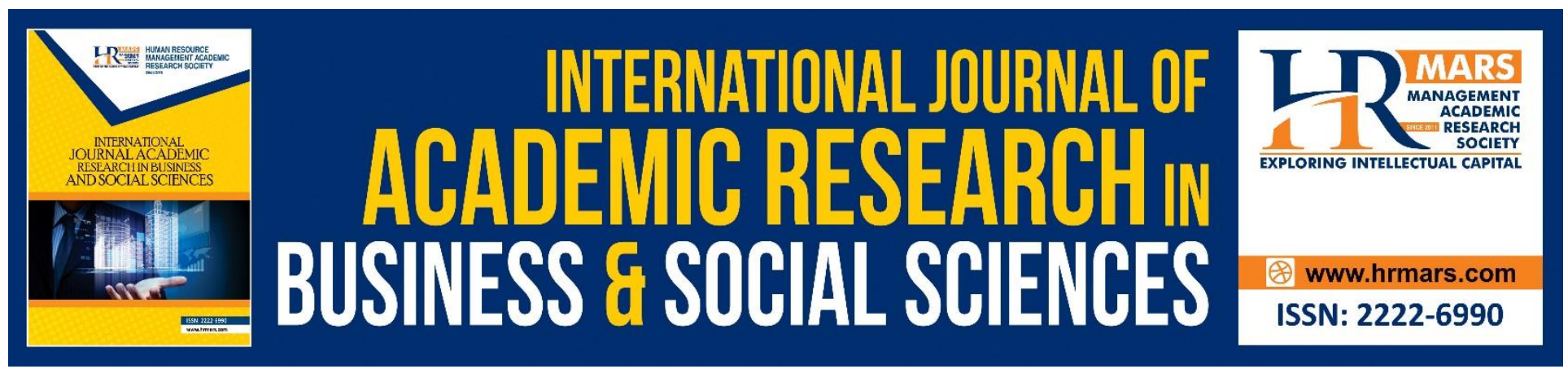

\title{
ECOWAS Single Currency and the Political Constrains
}

\section{Abdullahi Shehu Yusuf, Abdullahi Ayoade Ahmad, Maisara Nuhu Wali}

To Link this Article: http://dx.doi.org/10.6007/JJARBSS/v8-i9/4636

DOI: $\quad 10.6007 /$ IJARBSS/v8-i9/4636

Received: 13 August 2018, Revised: 04 September 2018, Accepted: 21 September 2018

Published Online: 20 October 2018

In-Text Citation: (Yusuf, Ahmad, \& Wali, 2018)

To Cite this Article: Yusuf, A. S., Ahmad, A. A., \& Wali, M. N. (2018). ECOWAS Single Currency and the Political Constrains. International Journal of Academic Research in Business and Social Sciences, 8(9), 537-546.

\section{Copyright: (C) 2018 The Author(s)}

Published by Human Resource Management Academic Research Society (www.hrmars.com)

This article is published under the Creative Commons Attribution (CC BY 4.0) license. Anyone may reproduce, distribute, translate and create derivative works of this article (for both commercial and non-commercial purposes), subject to full attribution to the original publication and authors. The full terms of this license may be seen at: http://creativecommons.org/licences/by/4.0/legalcode

Vol. 8, No. 9, September 2018, Pg. 537 - 546

Full Terms \& Conditions of access and use can be found at http://hrmars.com/index.php/pages/detail/publication-ethics 


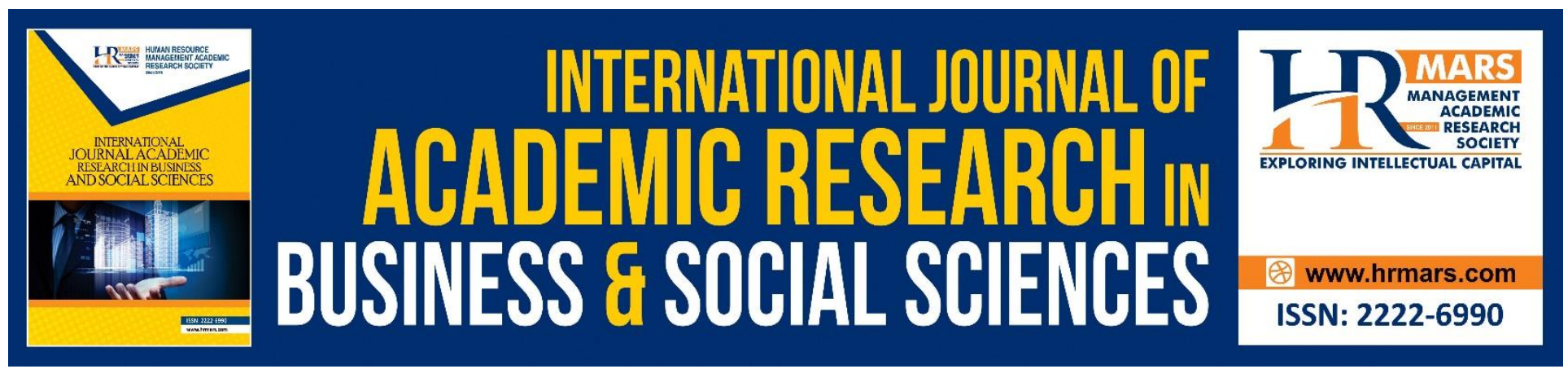

\title{
ECOWAS Single Currency and the Political Constrains
}

\author{
Abdullahi Shehu Yusuf ${ }^{1}$, Abdullahi Ayoade Ahmad², Maisara Nuhu \\ Wali $^{3}$ \\ ${ }^{1,2}$ Faculty of Law and International Relations, Universiti Sultan Zainal Abidin, (UNISZA) Campus Gong \\ Badak, 21300 Kuala Terengganu, Malaysia \\ ${ }^{3}$ Department of Political Science, Bayero University Kano (BUK), Kano, Nigeria \\ Corresponding Author: Abdullahi Shehu Yusuf \\ Email: abdullahishehuyusuf@yahoo.com
}

\begin{abstract}
Economic Community of West African States (ECOWAS), a regional institution comprising of fifteen nations. It emerged on May 281975 in Lagos Nigeria. One of the reasons behind the establishment is to ensure the existence of a single currency in the region. The desire to integrate the region into one economic bloc that will lead to the circulation of a single currency has been in the agenda of various regional heads of states conferences, but it was discovered that colonial loyalty and the long existing monetary cooperation of Francophone nations with France was a strong impediment towards the proposal of such target likewise member states have not been able to meet the set of convergence criteria which led to delays and shift of dates in establishing a common currency. In addition, there is lack of political will and fear of domination among ECOWAS member states. To solve this problem, it was agreed in April 2000 in Accra Ghana, a two-fast track approach strategy should be adopted for the realization of single currency. For the first track, the non-West African Economic and Monetary Union (WAEMU) were to form a second monetary union called the West African Monetary Zone (WAMZ) by July 2005, which comprises mainly of Anglophone nations, with the second track being the subsequent merging of WAEMU and WAMZ to form a single currency union in the region. This work examined the political constrain behind the constant shifting of dates for ECOWAS single currency integration, those obstacles and other unforeseen circumstances that had contributed to the delay from the target dates shifting from 2003 to 2005, 2009, 2015 and 2020 at present. The research is qualitative in nature as such document analysis was adopted. The finding will suggest way for accelerating the plan action and ensure the newly target will not lapse as before.
\end{abstract}

Keywords: ECOWAS, Single Currency, Political Constraints, European Influences, and Regional Leader 


\section{Introduction}

Following the trends towards globalization and the economies of scale derivable in largeness, numerous nations sharing common geographical location, language and culture found it imperative to come together as a regional body, aim at cooperating with one another in the areas of currency, security, trade, culture and sporting exchanges as well as free movement of citizens. People come together on the basis of certain parameters such as culture and common language owing to the need for self-preservation. This need for security and self-preservation makes communities and nations to integrate and emerge (Thomas, 2010). In West African, one of such regional institution was formed known as Economic Community of West African States (ECOWAS) through a treaty of May 28, 1975 in Lagos Nigeria on behalf of fifteen nations namely: Benin, Burkina Faso, Cape Verde, Cote d'Ivoire, Gambia, Ghana, Guinea, Guinea-Bissau, Liberia, Mali, Niger, Nigeria, Senegal, Sierra Leone and Togo. Among others, one of the primary purposes of ECOWAS is to achieve the use of a common currency in the region as a basic integrating factor, facilitating both trade and free movement of citizens. But several dates chosen for the realization of this objective has failed in the past and even the latest being 2015 was unrealistic.

ECOWAS was divided in their colonial loyalty to either Britain former colonies known as Anglophone West Africa, or France former colonies known as Francophone West Africa, both being the erstwhile colonial masters. Several efforts have been made to bridge this gap, thereby making the region an economic entity to realize the goal of a common currency. But the failure of several projected dates casts doubt as to the possibility of realizing the much expected monetary integration soon. Already, eight nations including Benin, Burkina Faso, Cote d'Ivoire, Guinea Bissau, Mali, Niger, Senegal, and Togo are using a single currency, the CFA which is tied to the Euro via the French treasury. All are former French colonies except Guinea Bissau that was colonized by Portuguese. The remaining six mainly English speaking nations of Gambia, Ghana, Guinea, Liberia, Nigeria and Sierra Leone have opted for a second monetary zone whose success will prepare the ground for future independent common currency in the region. While Cape Verde given the discretion to join either of the twofold zones. Since the attainment of ECOWAS common currency depends on the success of the second monetary zone, the objective of this research work is to look at the political constrain regarding the issue of Economic Community of West African States (ECOWAS) single currency (ECOWAS, 2014:14).

In an article published by ThisDay newspaper, Juliana Taiwo and Dele Ogbodo (2009) reported that, of the fifteen nations that make up ECOWAS, six including Gambia, Ghana, Guinea, Liberia, Nigeria and Sierra Leone belongs to West African Monetary Zone (WAMZ) while the rest belongs to the West Africa Economic and Monetary Union (WAEMU) francophone nations that has been using a common currency (CFA) dated back to 1960s. The authority of heads of states of WAMZ nations in their $24^{\text {th }}$ meeting of the convergence council of ministers in Abuja said that December, 2009 was no longer feasible for the take-off of its single currency and monetary union within the region. Under the revised plan, West African Monetary Zone (WAMZ) expects to launch the currency named "ECO" by 2015, while the entire ECOWAS will adopt a single currency by 2020 with the establishment of an ECOWAS Central Bank (Taiwo \& Dele 2009).

The most recent decision taking in July 2014 by the Heads of State is that the WAMZ single currency programme under the two-track approach has been merged with the ECOWAS wide single currency 
programme to form a single track to the ECOWAS single currency to be launched in 2020. This decision is reflected in the executive summary of the ECOWAS 2014 annual report which states: On the effort to fast-track improvement towards the realization of the ECOWAS single currency by 2020, the single track approach for the monetary integration programme was adopted leading to the rationalization of the macroeconomic convergence criteria and the revision of the roadmap for the ECOWAS single currency (ECOWAS, 2014:14).

\section{Purpose/Problem Statement}

Among the crucial motive for the ECOWAS establishment is to achieve the use of a common currency in the region as a basic integrating element, simplifying equally trade and free movement of citizens. But numerous dates chosen for the realization of this objective has failed in the past due to the certain reasons such as Political instability, Lack of political will among the ECOWAS nations, Fear of domination of weaker nations by the stronger one and Fear of loss of revenue with the formation of a single currency among others. Hence, the present study aims to examine why such factors hinder the actualization of the single currency by ECOWAS nation-states.

\section{Design/methodology/approach}

This research article employed and utilized qualitative documentary analysis (QDA) based on the preceding studies review. The utilization of this approach is justified owing to the fact that, reviewing the previous studies helps the researchers to easily pin point the weaknesses and strengths of other relevant studies which pave way for addressing such gaps in addition to coming-up with new findings.

\section{ECOWAS Regional Integration}

Regional integration according to the European Union is the process of removing economic, political as well as social barriers which sharply differentiated one country from its neighbors, and formation of economic linkages which will manage and share resources among countries for achieving common national goals by mutual agreement (Lolette Kritzinger-Van Niekerk, 2011, p.12). According to Luk Van Langenhove and Phillippe De Lombaerde, regional integration is the process of huge scale of disparities among territories with their lowering of internal boundaries and rising external borders for free movement of services, goods, capitals, and human in form of unification, reducing barriers and isolation (Amadu et al., 2011, p.11).

Mambara Jacqueline defined regional integration as the collaboration of countries that are close to each other in terms of economic linkages and geographical location to sign an agreement on trade and other economic activities (Amadu et al., 2011, p.12). Regional integration projects are essentially aimed at addressing the national interests of member individually and collectively. It is worth noting that, regional integration encompasses domestic peace and security in the integrating states because apart from the destruction of infrastructure such as road networks, telecommunications and other important amenities, conflict diverts attention from regional integration projects as it was the case in Liberia, Sierra Leone and Cote d'Ivoire during their civil wars. Second regional integration enhanced political and civic commitment and mutual trust among the members; third there must be a minimum threshold of macro-economic stability and good financial management among members state. According to S.K.B Asante regional integration refers to collaboration and cooperation with 
neighboring countries for achieving economic development (Amadu et al., 2011, Vol. 2 P 11). According to Thomas, as a result of the need for security and self-preservation, people with common language and culture used to come together to form communities. Such is imperative for security, self-preservation and other issues makes communities to integrate, and nations emerge for achieving their goal and development (Thomas, 2010, p.47).

The idea of regional integration of European Union inspired West African Heads of States and government to consider the idea and apply it to their region in order to solve their problems of security, political, economic and social issues. Regional integration in West Africa was motivated by the integration processes in Western Europe due to much commitment of E.U towards integration (Ogbeidi, 2010). According to Ogbonna and Ogundiwin, the emergence of the ECOWAS in 1975 by West African leaders through the signing of its treaty is a great achievement and success in the region and entire Africa. The region is heterogeneous in terms of historical background, colonialism and other complexities. By formation of ECOWAS, West Africa will achieve economic, security and political integration as well as cooperation (Ogbunna \& Ogundiwin, 2013, p.221).

\section{ECOWAS Monetary Integration}

Itsede stated that monetary integration is the monetary unification of participating member countries in economic union and involves the adoption of a common currency, coordinated exchange rate policies, and harmonization of fiscal and monetary policies (Itsede, 2002). Monetary integration provides the prospects of important benefits for participating countries, one advantage relate to the impact on resource improvement which is a central purpose of economic integration. This has two dimensions; in the first instance, monetary integration guarantees that currency restriction will never hinder trade between member countries. Moreover, the availability of convertible currency is clearly a basic requirement for effective market integration and for securing initial advantage of free trade among the group. Monetary integration also encourages the changes in investment allocation in the combined market that are required to secure full static gains from integration. Itsede further defined monetary integration as the existence of a single monetary zone with a high degree of monetary stability in the furtherance of economic integration. Monetary integration may be viewed as a continuum of arrangements ranging from what economists have labeled 'optimum currency area' to a full blown monetary union (Itsede, 2002).

There are boundless economic benefits when nations or group of nations agree to come together and cooperate at different levels; one of such level of cooperation is monetary union or currency union. West African Monetary Institute (WAMI) defined monetary union as an integral component of economic integration and evolutionary process that culminates in the adoption of a common monetary policy by a number of countries ceding sovereignty on monetary matters to a common monetary authority responsible for issuing a common currency Monetary integration involves the explicit harmonization of monetary policies and the common pool of foreign exchange reserves under the authority of a single Central Bank (WAMI, 2009).

Monetary integration provides the prospects of significant benefits for participating countries, one advantage relate to the impact on resource improvement which is a central purpose of economic integration. This has two dimensions; firstly, monetary integration guarantees that currency restriction will never hinder trade between member countries. Moreover, the availability of 
convertible currency is clearly a basic requirement for effective market integration and for securing initial advantage of free trade among the group. Monetary integration also encourages the changes in investment allocation in the combined market that are required to secure full gains from integration. The permanence of a monetary union requires a strong bond of solidarity among member countries. Accordingly, Cohen (1998) argued that in the absence of a dominant power with interest in making the arrangement function effectively on terms acceptable to all, there must be a genuine sense of community among the partners (Cohen, 1998).

The adoption of a single currency will assist the ECOWAS to come up with policies to ensure free mobility of capital, labor, goods and services within its members. It will greatly also enhance monetary and economic integration of its members. A single currency is also referred as an international or a common currency used by a union of national economies. It is adopted by sovereign nations, when they endow a single institution with authority to issue money, and conduct monetary policy on behalf of its members (Cohen, 1998).

Following the African reorientation towards economic integration, in 1987, ECOWAS adopted a programme of monetary cooperation as a means to facilitate regional trade and cross-border transactions and achieve regional currency convertibility (Ojo, 2001).

The foremost problem of currency union is the loss of sovereignty and the freedom to decide how a particular country can solve internal and external complications without consultation. Yet again, given the rampant corruption amongst the leadership of developing countries ECOWAS nations inclusive, and the inefficiency of democratic institutions and principles to instill discipline and control in policies and governance, the establishment of reference benchmarks to which a group must adhere to and then ceding power to control monetary policy to an independent institution can be a source of forced discipline (Cohen, 1998).

\section{Factors that leads to the ECOWAS Single Currency}

Political instability, religious and ethnic conflict posed severe challenges amongst the ECOWAS nation-states. After the struggle to put in place democratic government in these countries, the leaders are confronted with another dimension of the struggle within the region, which is to bring lasting peace and stability in these countries. Over the years, ECOWAS had to direct her energy and resources to resolving political crises within the region. There have been civil wars in Sierra Leone, Liberia, Cote d'Ivoire and Cape Verde. For instance the recent power tussle in Cote d'Ivoire was one of the distractions to the community development plan. It is worthy of note that in all these cases, ECOWAS was able to effect stability in these warring nations, using ECOMOG. One could also add that political instability that persists in the region is as a result of bad governance, high poverty and illiteracy. In order to ensure peaceful co-existence among ECOWAS nations, is to increase intra-trade among member countries, encourages freedom of movement of persons and facilitate the establishment of a single capital market.

Another factor that contributed to ECOWAS single currency is the issue of the adoption of euro as a single currency by the members of European Union (EU) which has heightened the desire of other regional blocs to achieve similar status. ECOWAS has made it an urgent goal to introduce single currency among its members. Besides, the EU has declared that it will not be dealing with individual 
INTERNATIONAL JOURNAL OF ACADEMIC RESEARCH IN BUSINESS AND SOCIAL SCIENCES

Vol. 8, No. 9, Sept. 2018, E-ISSN: 2222-6990 @ 2018 HRMARS

countries. This declaration has placed added burden on members of African, Caribbean and Pacific (ACP) countries to hasten their effort to become a viable economic bloc to enable them to maintain a common international voice in their political, trade and economic negotiations with other regional blocs.

\section{Factors that Contributed to the Actualization of ECOWAS Single Currency}

The issue of single currency has rather been challenging to achieve particularly in the ECOWAS as a result of many difficulties which incorporates:

First, Political instability: The West African region is experiencing a lot of challenges in dealing with the contemporary state of affairs of political, religious and ethnic conflict affecting the region. After the struggle to put in place democratic government in these countries, the leaders are confronted with another form of the struggle within the region, which is to bring lasting stability and peace. These have rather occupied the minds of the leaders than single currency issue. Over the years, ECOWAS had to direct her energy and resources to resolving political crises within the region. There have been civil wars in Sierra Leone, Liberia, Cote d'Ivoire and Cape Verde. For instance the recent power tussle in Cote d'Ivoire was one of the distractions to the community development plan. It is worthy of note that in all these cases, ECOWAS was able to effect stability in these warring nations, using ECOMOG. One could also add that political instability that persists in the region is as a result of bad governance, high poverty and illiteracy.

Chilleh stated that, Boko Haram insurgency and ethnic conflicts in Nigeria and Malian conflict have already assumed a frightful magnitude within the region. This is because a spillover of these crises from these countries if not checked could have devastating effect on the entire sub-region. He further states that all these and other flash points within the West African sub-region if not handled decisively; the desired stability will remain elusive. As a lasting solution to these incessant crises, ECOWAS leaders should develop the capacity for the true democracy, good governance, education, poverty alleviation and the rule of law in their respective nations (Chilleh, 2013). Second, Lack of political will among the ECOWAS nations to implement such articulated programme for economic growth and development. Members are unwilling to let go part their powers and sovereignty to the supranational body, which is the ECOWAS.

Third, Fear of domination of weaker nations by the stronger one, the weaker nation's fear that their sovereignty and freedom might be in danger if they form a single currency union with their bigger and more powerful neighbors. Such fear might be compounded by historical, socio-cultural and language differences in the case of ECOWAS countries where there exist strong potential for one group to dominate the other. That is, Anglophone vis-à-vis the Francophone countries. This poses a great challenge to the actualization of single currency in the region. Fourth, Geographical distance that is nearest to each other is essential in forming integration. Even if there is geographical proximity among the ECOWAS nations, they lack in good transportation, communication and infrastructural facilities to ensure effective integration.

Fifth, Fear of loss of revenue with the formation of a single currency is also an obstacle in the takeoff of monetary integration in the ECOWAS. This is because with monetary integration, intra-regional tariffs will be eliminated. By this, the weak members will not be in position to raise tariffs by 
INTERNATIONAL JOURNAL OF ACADEMIC RESEARCH IN BUSINESS AND SOCIAL SCIENCES

Vol. 8, No. 9, Sept. 2018, E-ISSN: 2222-6990 (C) 2018 HRMARS

themselves in order to meet their revenue requirements because they solely rely on tariffs, most of the countries are rather a market to foreign manufactured goods and only export primary products.

\section{Challenges Face by ECOWAS}

It is understandable that certainly no organization is free from one set of challenge or the other as such ECOWAS is not exceptional in this regard precisely on the single currency objective. The existence of multiple (multiplicity) of legal tender in ECOWAS is amongst the challenges regarding the realization of single monetary unification. There remain numerous nevertheless weak currencies in the province most of which are not exchangeable or convertible to each other except those ones attached, pegged or hanged on external currencies for instance franc CFA. Similarly, the presence of plentiful or multiple currencies generate exchanges rate risk and uncertainty as well, a problematic that is typically connected with the persistent of secretive trading in the form of cross boundary smuggling by intensifying unrecorded trade to be large. The smugglers customarily procure locally manufactured goods at low-cost and smuggled the goods to countries whose currency is convertible. Additionally, they utilized the sale profits to buy goods in that country and smuggled those backs to their nation state in consequence established a situation in which the local manufactures may perhaps not compete (De Grauwe, 2014).

\section{The Way forward}

At this juncture, it is worth noting that, for the latest 2020 date to be feasible to actualized single currency agenda, all hand must be on deck by the entire ECOWAS members to ensure the following:

$>$ Political stability that is, leaders must be committed to ensure the reign of peace and stability for the benefit of the entire ECOWAS countries in the region.

$>$ Leaders must have the political will to implement such single currency programme for economic development of the region at large.

$>$ The challenges of distrust and suspicion between members must to be tackle. Unless all countries of the ECOWAS are seen and treated as equal, the fear of domination will continue to exist in the region. Member countries must be seen to have equal voting rights in all matters that concern the union.

$>$ Intra-regional trades among the ECOWAS states need to be encouraged through campaigns and public enlightenment. A regional Board should be established to promote and encourage intra-trade in the region through the provision of subsidies to producers in the region to serve as motivational factor.

$>$ The ECOWAS countries should be encouraged to embark on the processing of the primary products from the region to export to members. They should also be encouraged to embark on industrialization.

$>$ ECOWAS countries ought to invest hugely in transport and communication infrastructural facilities; this will alleviate communication and transport barriers within the region.

$>$ The existing trade flows within ECOWAS countries are inadequate to yield economic benefits that could rationalize the establishment of a currency union, as such there require effort intensification towards expansion of trade flows amongst ECOWAS nations. 


\section{Conclusion}

The governments of ECOWAS countries must not leave any stone unturned to establish political stability, ethnic and religious harmony in their various states. The monetary integration is achievable by ECOWAS; leaders must in due course possess political will to implement such indigenously articulated programme for the development of the whole region. They should see themselves as one and understand how to solve their problems without interference from outsiders. They should come and work together in peace, harmony and tranquility for their political and economic development. Although there are expected technical hitches like it occurred in the case of European Union (EU), out of $28 \mathrm{EU}$ members only 19 countries are members of Euro Zone, simply because of economic disparity, it is expected that other members will follow suit. Regarding ECOWAS, with good will and togetherness, they can come together and form the single currency even without full members in the first place; the rest can join gradually until it is fully achieved. It is important at this juncture to note that a single monetary zone in ECOWAS is for the benefits of all member states and such benefit far outweigh any perceived cost. Therefore, there is need for re-orientation in the character of member states to comprehend and see beyond national boundaries and self-interest, which will furthermore simplify and ease working together in harmony towards the actualization of the monetary union for the betterment of the whole region.

\section{References}

Amadu, S. and Omotosho, M. (2011). "The politics of regional integration in West Africa." WACSERIES 2:2.

Anastasia, O. (2011). Comparative Regionalism: Euroasia Cooperation and European Integration: The case of neo-functionalism. Journal of Euroasia Studies 2(2011) 87-102

Anyanwu, J. C. (2003) "Does Monetary Union Affect Trade and Output" West African Journal of Monetary and Economic Integration, Vol.3(2): 1-23

Chilleh, F. F. (2013) "ECOWAS Standby Force a tool for sub-regional stability. Nigerian Army Information Brief March 2013.

De Grauwe, P. (2014) Economics of Monetary Union, Oxford University Press.

Economic Community of West African States (2014) ECOWAS Annual Report

Itsede, O. (2002). The challenges of monetary union: Gains and Opportunities. CBN Economic and Financial Review, 40 (4) Pp.50-51

Juliana, T. and D, Ogbodo. (2009) West Africa: ECOWAS Targets 2020 for Single Currency. This day, June, 23, 2009

Mambara, J. L. (2007). Assessment of Benefits of Regional Integration in SADC and COMESA-A Gender Analysis, Harare, Trade and Development Studies Centre, January

Niekerk, L. K. (2011). "Regional ntegration: Concepts Advantages, Disadvantages and Lessons of Experience." Retrieved March 15, 2014,from http://www.sarpn.org.za/.

Ogunkola, O. (2005) "An Evaluation of a Single Monetary Zone in ECOWAS" AERC Research paper No. 147, African Research Consortium.

Ogbeidi, M. (2010).Comparative Integration: A brief analysis of the European Union (EU) and Economic Community of West African States (ECOWAS). Journal of International Social Research 3:10. 
Ojo, M. O. (2001) The Prospects for Achieving the Objectives of the Second Monetary Zone in the West African Sub-Region. Journal of Monetary and Economic integration, 1, 45-67

Ojo, M. O. (2005) "Towards a Common Currency in West Africa: Progress, Prospects and Lessons." West African Journal of Monetary and Economic Integration Vol.5(2), pp.47-79.

Thomas, A.K. (2010). The Impact of ECOWAS for Political and Economic Cooperation Integration of West Africa: A Critical Analysis. A Collage paper presented at Armed Forces Command and Staff Collage Jaji, Nigeria.

WAMI (2009) State of Preparedness of WAMZ Countries for Monetary Union, Paper presented at WAMZ Convergence Council Meeting, Abuja.

Zhang, Y. \& Wildemuth, B. M. (2009). Qualitative analysis of content. Applications of social research method to questions in information and library science, 308-309

\section{Acknowledgement}

I would like to first and foremost extend my gratitude to Almighty Allah for the opportunity bestowed on me to conduct and completed this article successfully. Glory is to God.

\section{Corresponding Author}

Abdullahi Shehu Yusuf

Email: abdullahishehuyusuf@yahoo.com

Faculty of Law and International Relations, Universiti Sultan Zainal Abidin, (UNISZA) Campus Gong Badak, 21300 Kuala Terengganu, Malaysia 